\title{
Australian opposition pledges more funds
}

[SYDNEY] In a tightly fought election campaign in Australia, Kim Beazley, the leader of the opposition Labor Party, has proposed science and higher-education research initiatives costing about A $\$ 600$ million (US\$355 million) over three years, saying that this will lead to lower unemployment.

In contrast, the Liberal Party's science and education ministers have been low key and defended cuts by the conservative coalition, of which it has most members, to both sectors over its two-and-a-half years in office. But the Labor Party would need a large swing to regain power in the election, which takes place on Saturday (3 October).

Only some of Labor's proposed funding for science would need 'new money'. One bold suggestion is that 35 per cent of the profits of Telstra, Australia's largest company, should be spent on science and development projects outside the main cities.

Last year, the government sold off onethird of Telstra, a telecommunications company. John Howard, the prime minister, now wants to sell the remaining two-thirds. But Labor and minor parties are vigorously opposed to further privatization. Labor says that, if elected, it would set up a Telstra Reward Fund, the annual income of which would be the equivalent of the dividends earned by international shareholders if Telstra were fully sold.

Labor estimates that the fund's income in the first year would be sufficient to pay for grants awarded through the National Health and Medical Research Council, the 67 cooperative research centres and the Australian Institute of Marine Science, and pay for a Molecular Biology Research Institute, creating 350 jobs in Adelaide.

Labor's shadow science minister, Martyn Evans, says the Telstra plan would "isolate science from the normal slings and arrows of outrageous fortune of the budget process". $\mathrm{He}$ also argues that "flagging" support for science, from a public service heavily dependent on innovation, could increase public appreciation of science.

Beazley says that Labor's policies would raise business spending on research and development — currently falling fast - to more than one per cent of gross domestic product by 2005-2010, "restoring Australia's reputation as a clever country".

Evans says a A $\$ 300$ million research reactor - Australia's largest investment in a science facility - would not be built on a site in Sydney chosen by the ruling coalition, and the necessity for one anywhere else would be reviewed. The minority Democrats Party, which is likely to hold a balance of power in the Senate, is totally opposed to it.

Brian Anderson, the president of the Academy of Science, says he is "alarmed and dismayed" at recent evidence of a fall in industrial research and development (see Nature 394, 512; 1998), and describes Labor's promise to restore tax concessions as "a starting point for constructing a taxation regime for innovation that will work".

In a costly advertising campaign fronted by Sir Gustav Nossal, previously director of the Walter and Eliza Hall Institute for Medical Research in Melbourne, university vicechancellors have called for about $\mathrm{A} \$ 1$ billion cut from universities' budgets to be restored.

The vice-chancellors have greeted Labor's proposals - which include the reversal of a substantial reduction to the Australian Research Council foreshadowed in the coalition's budget last May — as "the first breath of fresh air in a long time".

John Moore, the minister for industry and science in the current government, has promised increased funding for a new scheme that provides competitive grants to industry, and modest initiatives in marine science and wetlands research. But Anderson says the country's problems are "only lightly touched" by such suggestions. Peter Pockley

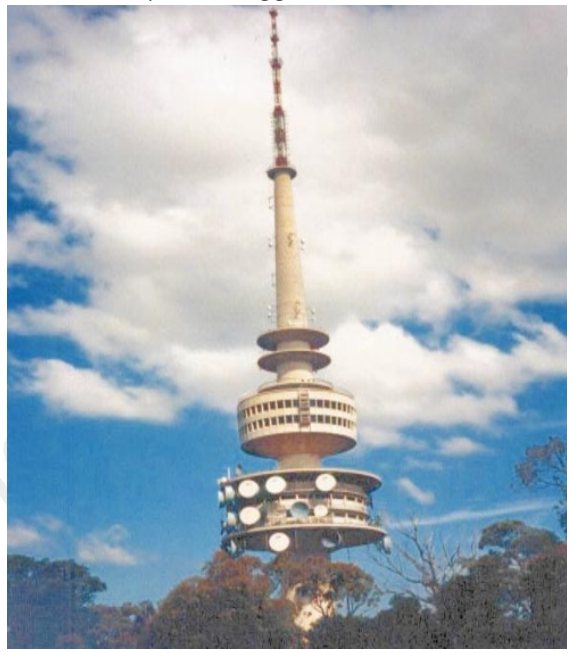

Canberra's Telstra Tower: Labor wants Telstra's image - and profits - to boost science.

\section{NIH ponders role of 'public' advisers}

[WASHINGTON] Harold Varmus, the director of the National Institutes of Health (NIH), last week turned to 25 individuals - from an Illinois farmer's wife to a former African ambassador — for advice on establishing a Council of Public Representatives.

The move represents Varmus's swift response to a report published three months ago by the Institute of Medicine (IOM) at the request of Congress that criticized the NIH for failing to communicate effectively with the public (see Nature 394, 111; 1998).

The council, which Varmus hopes to have in place within six months, was recommended by the IOM report as a way of improving relations between the NIH and the public by getting ordinary people's opinions directly to Varmus.

Addressing a public meeting of the 25 individuals, Varmus added that he has already implemented another of the report's recommendations by establishing public liaison offices in all $24 \mathrm{NIH}$ institutes and centres. And he is also acting on another IOM suggestion: adding public members to the director's advisory committee.

While Varmus stressed that the IOM had issued "recommendations, not orders", he said that the NIH "can always do better" with public relations, and he sees a valuable role for the new council. "It would be very helpful to me as we go through debates about issues where science touches society that I have some standing body that has more public participation, that can give me advice," he said.

In the course of the day-long meeting, however, it became clear that defining the role and composition of the body will not be simple. Some participants wanted the group to have a clear hand in advising Varmus on research priorities, the larger subject of the IOM report.

Others, however, argued that it would not be scientifically equipped for such a role, and would be more effective focusing on broader issues, such as the public's concerns about medical privacy.

Rashi Fein, a professor of the economics of medicine at Harvard Medical School, suggested that the group should focus on "certain gaps in the sensitivity of the medical science community". But Amalie Ramirez, associate director of the Baylor College of Medicine Center for Cancer Control Research in San Antonio, Texas, was worried that the council might then be relegated to a "public relations function".

Still others argued that neither the council nor the public liaison offices address what they perceive as the problem underlying NIH's public relations efforts: the agency's apparent blindness to perceived imbalances in how it distributes its \$14 billion annual budget among diseases.

But Varmus cautioned against a council structured in such a way that meetings became "a divisive debate among constituencies wanting bigger shares of the pie". He called for the group to help develop membership criteria that would offer him "protection" from the demands of various advocacy groups to be included in the council. 